\title{
RESÚMENES DE TESIS
}

Valeska Cabrera Silva. La reforma de la música sacra en la Catedral Metropolitana de Santiago de Chile (18501939). Tesis para la obtención del Doctorado en Musicología con Mención Internacional. España: Universidad de Salamanca, Facultad de Geografía e Historia, Departamento de Didáctica de la Expresión Musical, Didáctica y Corporal, 2016, 658 pp. Director: Dr. José Máximo Leza. Codirector: Dr. Alejandro Vera.

Se conoce como reforma de la música sacra al proceso mediante el cual la Iglesia católica intentó regular la música que se ejecutaba dentro de las funciones litúrgicas. Si bien tomó como base muchos postulados emitidos a lo largo de los siglos anteriores, dicho concepto define particularmente a los planteamientos formulados a partir de las primeras décadas del siglo XIX en la Santa Sede, a los que se sumaron posteriormente otras líneas de acción, como el movimiento litúrgico y el cecilianismo. En términos generales, se buscó restituir estilos musicales antiguos, como el canto gregoriano y la polifonía sacra del siglo XVI, y se rechazaron los géneros catalogados como "profanos", principalmente la ópera italiana. Este movimiento se expandió durante varias décadas, alcanzando un estatus oficial para todo el mundo católico cuando el papa Pío X publicó el Motu Proprio Tra le Sollecitudini en 1903.

En esta tesis se examina el desarrollo de este proceso en Chile, focalizándose en la actividad musical de la Catedral Metropolitana de Santiago entre 1850 y 1939. Las hipótesis barajadas fueron: primero, que la iglesia católica chilena se integró a la reforma de la música sacra de forma temprana, a partir de la década de 1840; segundo, que, además de obedecer a las directrices impuestas por la Santa Sede, la iglesia católica chilena incorporó elementos que dotaron a este proceso de características locales particulares que tuvieron consecuencias sobre la práctica musical, y tercero, que dichas singularidades apuntaron fundamentalmente a los aspectos teórico-interpretativos más que a la composición musical, la que por esta misma razón no habría sido mayormente incentivada.

A partir de estas hipótesis la tesis establece el rol protagónico ejercido por el segundo arzobispo de Santiago, Rafael Valentín Valdivieso (1845-1878), cuyas acciones en relación con lo musical se vincularon a esta reforma desde sus primeros años en el cargo. Su impronta trascendió incluso su muerte, pues sus medidas principales tuvieron efecto con posterioridad, como ocurrió con la preferencia por el repertorio europeo para la Catedral y la preeminencia -no exclusiva- de la música con acompañamiento de órgano en desmedro de la acompañada por orquesta. Asimismo, desde su gestión continuaron siendo los jerarcas más altos de la Iglesia chilena los que condujeron este proceso, con la excepción representada por el maestro de capilla Vicente Carrasco a principios del siglo XX.

De este modo, esta tesis ofrece una vasta visión de la actividad musical de la Catedral Metropolitana de Santiago entre 1850 y 1939, analiza sus hechos más relevantes, aporta evidencia documental inédita y ofrece nuevas perspectivas, ampliando el campo de conocimiento que se tenía hasta el momento respecto de esta materia.

Valeska Cabrera Silva

Musicóloga, Chile valeska.cabrera@gmail.com 